\title{
Busting Arbitration Myths
}

\author{
Christopher R. Drahozal
}

INTRODUCTION

The Discovery Channel show MythBusters has been described as perhaps the "best science show on television." On each show Jamie Hyneman and Adam Savage (and their "build team") test various "myths" - urban legends or commonly held views about some event or phenomenon. $^{2}$ On recent episodes, the MythBusters have tested the extent to which the coating on the skin of the Hindenburg contributed to the 1937 disaster (the skin was painted with layers of aluminum powder and iron oxide-which, when combined in proper proportions, make thermite); whether you save energy by leaving a light bulb on, rather than turning it off when leaving a room and back on again when returning; and whether it is possible to teach an old dog new tricks. ${ }^{3}$ The show does an impressive job of recreating the original conditions of the myths and adhering to the scientific method in testing them-and, more importantly, often ends with cool crashes or explosions.

In this paper, I will present an "arbitration" version of MythBusters - testing several commonly held myths about arbitration (private judging). Jamie and Adam give a standard warning at the start of every MythBusters show, which I will reiterate here: "Remember, don't try this at home. We're what you call "experts." 4 The warning is not nearly as necessary here, of course, since (sorry to say) I will not be crashing any vehicles or setting off any explosions. Nonetheless, I do hope to share some of what I have learned about arbitration over the past several years, and perhaps "bust" some myths in the process.

\footnotetext{
John M. Rounds Professor of Law, University of Kansas School of Law. This paper is a revised version of my Inaugural Lecture as Rounds Professor, presented at the University of Kansas on April 30, 2007.

1. John Schwartz, The Best Science Show on Television?, N.Y. Times, Nov. 21, 2006, at A1.

2. What's a MythBuster?, http://dsc.discovery.com/fansites/mythbusters/about/about.html (last visited Apr. 27, 2008).

3. Annotated MythBusters, http://kwc.org/mythbusters/ (last visited Apr. 27, 2008).

4. Internet Movie Database, Memorable Quotes for "MythBusters," http://www.imdb.com /title/tt0383126/quotes (last visited Apr. 27, 2008).
} 


\section{WHAT IS ARBITRATION?}

The American Arbitration Association (AAA) defines arbitration as the "submission of a dispute to one or more impartial persons for a final and binding decision." "Instead of going to court and having a judge or jury resolve their dispute, the parties hire their own judge (who may be a lawyer or an expert in a particular industry). ${ }^{6}$ Parties can agree to arbitrate after a dispute arises. More commonly, they agree to arbitrate before any dispute arises by including an arbitration clause in the contract they have signed.

I always start my arbitration class by asking my students about their prior experience with arbitration (and do the same when I speak to lawyers and judges on the topic). When I ask whether any are party to an arbitration agreement, very few raise their hands. But when I ask them one of the following questions-Have you purchased stock through a brokerage firm? ${ }^{7}$ Have you bought a Dell or Gateway computer (although not an HP/Compaq computer, last I checked) $?^{8}$ Do you have a credit card? ${ }^{9}$ Do you have a cell phone (at least a Sprint or Verizon cell phone) $?^{10}$ - the response is overwhelmingly affirmative. Sellers of each of these products or services commonly include an arbitration clause in their standard contract terms and conditions. One illustration is the dispute resolution clause in the General Terms and Conditions of Service governing the use of a Sprint cell phone. Under those terms and conditions, after making an effort to resolve any dispute informally, the parties commit to use arbitration in lieu of going to court: "We each agree to finally settle all disputes (as defined and subject to any specific exceptions below) only by arbitration." 11

5. American Arbitration Association, a Guide to Mediation and Arbitration for BUSINESS PEOPLE 5 (2007), available at $\mathrm{http}: / / \mathrm{www}$.adr.org/si.asp?id=4121.

6. By comparison, mediation "is a process in which a neutral assists the parties in reaching their own settlement but does not have the authority to make a binding decision." Id.

7. See NASD Manual, Rule 12200 (effective Apr. 16, 2007).

8. See Christopher R. Drahozal \& Raymond J. Friel, Consumer Arbitration in the European Union and the United States, 28 N.C. J. INT'L L. \& COM. REG. 357, 379-83 (2003).

9. See Linda J. Demaine \& Deborah R. Hensler, "Volunteering" to Arbitrate Through Predispute Arbitration Clauses: The Average Consumer's Experience, 67 LAW \& CONTEMP. PROBS., Winter/Spring 2004, at 55, 64.

10. See Sprint General Terms and Conditions of Service, http://www.sprintpcs.com/common/ popups/popLegalTermsPrivacy.html?id16=terms_and_conditions (last visited Apr. 27, 2008) [hereinafter Sprint Terms \& Conditions]; Verizon Wireless Customer Agreement, http://www. verizonwireless.com/b2c/globalText?textName=CUSTOMER_AGREEMENT\&jspName $=$ footer $/$ cus tomerAgreement.jsp\&textName=CUSTOMER_AGREEMENT\&jspName=footer/customerAgreeme nt.jsp (last visited Apr. 27, 2008).

11. Sprint Terms \& Conditions, supra note 10. 
The use of arbitration clauses in consumer (and employment) contracts, as illustrated by these examples, has been very controversial. ${ }^{12}$ But arbitration is used in other contexts as well. Arbitration clauses appear in contracts ranging from franchise agreements (contracts between franchisors and franchisees, such as McDonald's Corporation and the person who runs the local McDonald's restaurant) ${ }^{13}$ to international joint venture contracts. ${ }^{14}$

One typical characteristic of arbitration in all of these contexts is that it is secret: unlike court hearings, which ordinarily are held in open court, arbitration proceedings are private. ${ }^{15}$ As a result, information on what happens in arbitration is hard to come by, creating a fertile ground where myths can develop and thrive. Researchers have begun to investigate what goes on in arbitration, replacing anecdotes with data. ${ }^{16}$ In the rest of this paper, I will examine the results of some of that research to testand either "confirm" or "bust"- the following three myths:

Myth 1: Do new arbitration laws attract more arbitration business?

Myth 2: Do parties agree to have arbitrators apply the Law Merchant (in lieu of national law) in resolving disputes?

Myth 3: Do arbitrators "split the baby"-i.e., make compromise awards?

12. Compare Jean R. Sternlight, Panacea or Corporate Tool?: Debunking the Supreme Court's Preference for Binding Arbitration, 74 WASH. U. L.Q. 637 (1996) (critiquing pre-dispute arbitration clauses in consumer contracts), with Stephen J. Ware, The Case for Enforcing Adhesive Arbitration Agreements-With Particular Consideration of Class Actions and Arbitration Fees, 5 J. AM. ARB. 251 (2006) (defending pre-dispute arbitration clauses in consumer contracts).

13. Christopher R. Drahozal, "Unfair" Arbitration Clauses, 2001 U. ILL. L. REV. 695, 726-27 ( $45 \%$ of franchise agreements studied included an arbitration clause).

14. Christopher R. Drahozal \& Richard W. NAimark, TOWARdS A ScIence of INTERNATIONAL ARBITRATION: COLLECTED EMPIRICAL RESEARCH 59 (2005) (almost $90 \%$ of international joint venture contracts studied included an arbitration clause). The use of arbitration clauses in international contracts varies with the type of contract, however. See Theodore Eisenberg \& Geoffrey P. Miller, The Flight from Arbitration: An Empirical Study of Ex Ante Arbitration Clauses in the Contracts of Publicly Held Companies, 56 DEPAUL L. Rev. 335, 351 (2007).

15. Amy J. Schmitz, Untangling the Privacy Paradox in Arbitration, 54 U. KAN. L. REV. 1211, 1211 (2006); Richard C. Reuben, Confidentiality in Arbitration: Beyond the Myth, 54 U. KAN. L. REV. 1255, 1255-56 (2006).

16. Jack J. Coe, Jr., From Anecdote to Data: Reflections on the Global Center's Barcelona Meeting, 20 J. INT'L ARB. 11 (2003). For surveys of empirical research on international commercial arbitration, see Christopher R. Drahozal, Arbitration by the Numbers: The State of Empirical Research on International Commercial Arbitration, 22 ARB. INT'L 291 (2006); Christopher R. Drahozal, Of Rabbits and Rhinoceri: A Survey of Empirical Research on International Commercial Arbitration, 20 J. INT'L ARB. 23 (2003). For a collection of empirical studies, see DRAHOZAL \& NAIMARK, supra note 14. For a study using data to assess several empirical claims about investment treaty arbitration, see Susan D. Franck, Empirically Evaluating Claims About Investment Treaty Arbitration, 86 N.C. L. REV. 1 (2007). 


\section{Myth 1: Do New Arbitration Laws AtTract More Arbitration BUSINESS?}

Governments, like businesses, compete with each other. At the local level, such competition is most visible in the tax incentives state and local governments give businesses to relocate. ${ }^{17}$ Cities compete by building new sports arenas to keep or attract professional sports teams (as in Kansas City's unsuccessful attempt to woo the Pittsburgh Penguins hockey team to the new Sprint $\operatorname{Center}^{18}$ ). A frequently discussed example of competition among states involves corporate charters-states compete by revising their corporate laws to attract businesses to incorporate in the state. Whether the resulting changes in state corporation codes benefit shareholders is a hotly debated topic-does the competition result in a "race to the bottom"

Countries also compete to attract business - such as by updating their arbitration laws. Many have commented on the competition: Pieter Sanders, the "principal architect" 21 of the New York Convention, ${ }^{22}$ has stated that "[m]odernization of arbitration laws is inspired by the desire to make arbitration more attractive to its users. A certain competition between countries to attract arbitration ... can be noted." 23 According to Tom Carbonneau, "[c]ountries have, without shame, exhibited their desire to attract the business of arbitration" by "climb[ing] on the 'hospitable-jurisdiction-to-arbitration' bandwagon." 24

17. Walter Hellerstein \& Dan T. Coenen, Commerce Clause Restraints on State Business Development Incentives, 81 CORNELL L. REV. 789, 790-91 (1996).

18. Kansas City Offers Penguins Free Rent, Ownership Stake, Jan. 4, 2007, http://sports.espn. go.com $/$ nhl/news/story?id=2720130.

19. Lucian Arye Bebchuk \& Allen Ferrell, Federalism and Corporate Law: The Race to Protect Managers from Takeovers, 99 CoLuM. L. REV. 1168 (1999); Lucian Arye Bebchuk, Federalism and the Corporation: The Desirable Limits on State Competition in Corporate Law, 105 HARV. L. ReV. 1435 (1992); William L. Cary, Federalism and Corporate Law: Reflections upon Delaware, 83 YALE L.J. 663 (1974).

20. Roberta Romano, The Genius of American Corporate LaW (1993); Ralph K. Winter, Jr., State Law, Shareholder Protection, and the Theory of the Corporation, 6 J. LEGAL StUd. 251 (1977); Ralph K. Winter, The "Race for the Top" Revisited: A Comment on Eisenberg, 89 ColuM. L. REV. 1526 (1989).

21. Albert Jan van den Berg, Striving for Uniform Interpretation, in U.N. COMM'N ON INT'L

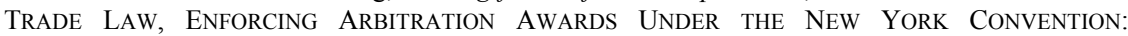
EXPERIENCE AND PROSPECTS at 40, 40, U.N. Sales No. E.99.V2 (1998), available at http://www. uncitral.org/pdf/english/texts/arbitration/NY-conv/NYCDay-e.pdf.

22. Convention on the Recognition and Enforcement of Foreign Arbitral Awards, June 10, 1958, 21 U.S.T. 2517, 330 U.N.T.S. 3.

23. Pieter Sanders, Arbitration, in XVI-12 INTERNATIONAL ENCYCLOPEDIA OF COMPARATIVE LAW § 12-29, at 18 (Mauro Cappelletti ed., 1996).

24. Thomas E. Carbonneau, Cases and Materials on the LaW and Practice of ARBITRATION 1143 (2d ed. 2000). 
As with state competition in corporate law, there is always the question of whether the competition is good or bad. But that is not the question I will be addressing here (and it is a difficult one to answer, as the research on corporate charters suggests). Instead, the myth I will be testing is whether becoming a "hospitable jurisdiction to arbitration" works - that is, whether by updating its arbitration law a country in fact attracts more arbitration proceedings to be held in the country.

Politicians certainly claim that it does, at least when they are trying to get a new arbitration law enacted. Miss M. Wallace, Irish Minister of State at the Department of Justice, Equality and Law Reform, stated (in support of Ireland's enactment of the UNCITRAL Model Law on International Commercial Arbitration ${ }^{25}$ ) that "a modern arbitration law, for which the Bill provides, has the potential to attract valuable arbitration business to this State." 26 More dramatically, Lord Cullen of Ashbourne asserted (during parliamentary debates on the English Arbitration Act of 1979) "that a new arbitration law might attract to England as much as $£ 500$ million per year of 'invisible exports,' in the form of fees for arbitrators, barristers, solicitors, and expert witnesses." 27

Lord Cullen's statement highlights the asserted benefits of attracting arbitration proceedings to be held in a country-among others, that parties are more likely to select the country's arbitrators and lawyers for the arbitrations. ${ }^{28}$ But his quantification of that benefit is astounding: $£ 500$ million per year in 1979 translates to roughly $\$ 3.5$ billion in today's U.S. dollars. ${ }^{29}$ The amount seems unbelievably high; it simply cannot be

25. Ireland enacted the UNCITRAL Model Law in 1998. See Arbitration (International Commercial) Act, 1998 (Act No. 14/1998) (Ir.), reprinted in 2 INT'L COUNCIL FOR COMMERCIAL ARB., INTERNATIONAL HANDBOOK ON COMMERCIAL ARBITRATION, Ireland: Annex III at 1 (Jan. 2000).

26. Debates of the Houses of the Oireachtas on Arbitration (International Commercial) Bill, 1997: Second Stage, 155 SEANAD DEB. col. 784 (May 14, 1998), available at http://historicaldebates.oireachtas.ie/S/0155/S.0155.199805140005.html (remarks of Miss M. Wallace, Minister of State at the Department of Justice, Equality and Law Reform); id. at col. 780 (remarks of Mrs. Taylor-Quinn) ("[The bill] will strengthen Ireland's position and I believe we will succeed in securing a great deal of international business here as a result of it.”); Press Release, O'Donoghue Publishes Bill Designed to Attract International Inward Investment to Ireland (Oct. 2, 1997) (on file with author) ("The economies of other countries have benefited considerably from arbitration business and there is no reason why Ireland should not share in those benefits.") (quoting John O’Donoghue, Minister for Justice, Equality and Law Reform).

27. William W. Park, Judicial Supervision of Transnational Commercial Arbitration: The English Arbitration Act of 1979, 21 HARV. INT'L L.J. 87, 96 (1980) (quoting 392 PARL. DEB., H.L. (5th ser.) (1978) 99).

28. Christopher R. Drahozal, Arbitrator Selection and Regulatory Competition in International Arbitration Law, in DRAHOZAL \& NAIMARK, supra note 14, at 167-68 (finding that number of arbitrators selected from country increases after country enacts new arbitration law).

29. Converted to March 2007 British pounds using data from Series CDKO: Long Term Indicator of Prices of Consumer Goods and Services (Jan. $1974=100$ ), available at http://www. 
right. Indeed, that seems to be the case. As Yves Dezalay and Bryant Garth have stated:

In England, the partisans of reform of arbitration estimated that millions of pounds were being lost to London and its legal profession from the fact of legislation perceived by their foreign counterparts as too restrictive and costly. The same individuals today admit that the estimates, widely reported by the press, were complete inventions. ${ }^{30}$

So how to test this myth? The ICC (the International Court of Arbitration of the International Chamber of Commerce), which has been called the "central institution" in international commercial arbitration, ${ }^{31}$ publishes data on the countries in which ICC-administered arbitrations take place. Using those data (from 1994 to 1999), and controlling for a number of factors that might affect how many arbitration proceedings are held in a country, I estimated that the number of ICC arbitration proceedings held in a country does in fact increase (by a statistically significant amount) after the country enacts a new arbitration law. ${ }^{32}$ For all the countries studied, the number of ICC arbitration proceedings increased by almost $19 \%$ after enactment of a new law. For larger countries, which were better established as arbitral sites, the number of ICC arbitration proceedings increased by almost $27 \% .{ }^{33}$ Thus, the basic myth - that countries can attract new arbitration business by revising their arbitration laws - is, in MythBusters' parlance, confirmed.

But what about Lord Cullen's prediction, that in 1979 a new arbitration law could have resulted in "as much as $£ 500$ million per year of "invisible exports" for the UK? To my knowledge no data are available for that time period. What do the more recent data from the ICC indicate? While the increase in arbitrations following enactment of a new statute was large in percentage terms, it was quite small in absolute numbers. For all countries in the sample, the average increase was at most two arbitration proceedings per year. ${ }^{34}$ For larger countries,

statistics.gov.uk/statbase/tsdtimezone.asp (select "Consumer Price Indices"; then select "3.5: RPI all items long run ..."; then select "CDKO: Long Term Indicator . ..") (last visited Apr. 27, 2008) (1979 index $=223.5$; Mar. 2007 index $=806.4)$, and converted from pounds to dollars using the exchange rate as of 4:02 p.m. EDT on April 26, 2007, available at http://money.cnn.com/data/ currencies/index.html (last visited Apr. 26, 2007) $(£ 1=\$ 1.991)$.

30. Yves Dezalay \& Bryant G. Garth, DEALING IN VirTUE 299 n.21 (1996).

31. Id. at 45

32. Christopher R. Drahozal, Regulatory Competition and the Location of International Arbitration Proceedings, 24 INT'L REV. L. \& ECON. 371 (2004).

33. Id. at 383 .

34. Id. at 382 
the increase was roughly eight to ten arbitrations per year. ${ }^{35}$ Assuming each arbitration had an average amount at stake (arbitrator fees in ICC proceedings are based on the amount in controversy in the dispute), and making generous assumptions about the other financial benefits a country might obtain from serving as the place of arbitration, enactment of a new arbitration statute was worth less than $\$ 600,000$ per year for a larger country. ${ }^{36}$ Certainly the ICC is only one of a number of institutions that administer arbitration proceedings, albeit one of the most important, ${ }^{37}$ and the financial estimates are quite rough. Even with these caveats, however, this part of the myth seems pretty clearly to be busted.

\section{Myth 2: Do Parties Agree to HaVe ARBITRATORS APPly the LAW MERCHANT (IN LIEU OF NATIONAL LAW) IN RESOLVING DISPUTES?}

A recurring controversy in international arbitration practice is the extent to which parties seek to have their disputes resolved not based upon any national law, but upon "general principles of international commercial law"-also known as the lex mercatoria, or Law Merchant. The original (or "medieval") Law Merchant was developed, the traditional story goes, by merchant courts resolving disputes among merchants in medieval fairs. ${ }^{38}$ The result of this private dispute resolution process, according to Bruce Benson, was that "[v]irtually every aspect of commercial transactions in Europe was governed for several centuries by this privately produced, privately adjudicated and privately enforced body of law."

A more familiar example of this sort of industry-developed law can be found in the 2003 movie Pirates of the Caribbean, inspired by the Disneyland ride with the same name. ${ }^{40}$ Throughout the movie, characters refer repeatedly to the "Code of the Brethren, set down by the

35. Id.

36. Id.

37. DRAHOZAL \& NAIMARK, supra note 14, at 341 app. 1.

38. Harold J. Berman, Law and Revolution: The Formation of the Western Legal TRADITION 333 (1983) ("It was then that the basic concepts and institutions of modern Western mercantile law_lex mercatoria ('the law merchant') - were formed, and, even more important, it was then that mercantile law in the West first came to be viewed as an integrated, developing system, a body of law."). For contrary views, see infra note 52.

39. Bruce L. Benson, Law Merchant, in 2 The NeW Palgrave Dictionary of Economics AND THE LAW 500, 500 (Peter Newman ed., 1998).

40. Pirates of the Caribbean: The Curse of the Black PeARl (Walt Disney Pictures 2003). I have made this comparison previously. See Christopher R. Drahozal, The Making of the Award: Comments on Case Law Developments Under the UNCITRAL Model Law, 8 INT'L ARB. L. REV. 183, 186 (2005). 
pirates Morgan and Bartholomew"- that is, the "Pirates' Code."41 The Pirates' Code (some versions of which evidently did exist in real life ${ }^{42}$ ) was a set of rules developed and enforced by pirates themselves, governing behavior by pirates toward other pirates-what might be called a pirate "Law Merchant.",43

The idea of the new Law Merchant is similar: that international arbitrators (rather than pirates) develop general principles of commercial law while resolving disputes among merchants in private courts. ${ }^{44}$ The new Law Merchant has been the subject of extensive scholarship. Numerous books, articles, and websites discuss the theory of the lex mercatoria and attempt to catalog its principles ${ }^{45}$ (notably, however, one leading authority describes the haul as a very modest one $\left.{ }^{46}\right)$.

Normative views on the new Law Merchant vary. Benson contends that customary law, such as the lex mercatoria, is superior to publicly-

41. See Internet Movie Database, Memorable Quotes for Pirates of the Caribbean: Curse of the Black Pearl, http://www.imdb.com/title/tt0325980/quotes (last visited Apr. 27, 2008).

42. Cathy Schultz, History in the Movies: Pirates of the Caribbean, http://www.stfrancis.edu/ historyinthemovies/Pirates.htm (last visited Apr. 27, 2008) ("[T]he 'Code' did exist as an historical fact, and similarly to the movie, involved issues of fairness among the pirates. 'No prey, no pay' was a common principle, but equality in the shares of the plunder was also valued."); see also Peter T. Leeson, An-aargh-chy: The Law and Economics of Pirate Organization, 115 J. POL. ECON. 1049, 1069-76 (2007) (analyzing "pirate constitutions").

43. Of course in the movie, according to pirate Captain Barbossa, "the Code is more what you'd call 'guidelines' than actual rules." Internet Movie Database, Memorable Quotes for Pirates of the Caribbean: The Curse of the Black Pearl, http://www.imdb.com/title/tt0325980/quotes (last visited Apr. 27, 2008).

44. Actually, the phrase "lex mercatoria" has various meanings:

Lex mercatoria seems to mean different things to different people .... [T] he various

notions may usefully be distinguished and grouped under three headings. First, the most ambitious concept of lex mercatoria is that of an autonomous legal order, created spontaneously by parties involved in international economic relations and existing independently of national legal orders. Second, lex mercatoria has been viewed as a body of rules sufficient to decide a dispute, operating as an alternative to an otherwise applicable national law. Third, it may be considered as a complement to otherwise applicable law, viewed as nothing more than the gradual consolidation of usage and settled expectations in international trade.

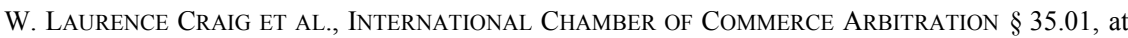
623 (3d ed. 2000). My focus here is on the first two meanings, which involve the lex mercatoria as a substitute for national law, rather than the third. See Christopher R. Drahozal, Contracting Out of National Law: An Empirical Look at the New Law Merchant, 80 Notre Dame L. REV. 523, 529 (2005).

45. See, e.g., Klaus Peter Berger, The Creeping Codification of the Lex Mercatoria (1999); CRAIG ET AL., supra note 44, §§ 35.01-.04; LEX MERCATORIA AND ARBITRATION (Thomas E. Carbonneau ed., rev. ed. 1998); Clive M. SchmitThoff, InTERnAtional TRAdE USAGES 43-73 (1987); Rt. Hon. Lord Justice Mustill, The New Lex Mercatoria: The First Twenty-five Years, 4 ARB. INT'L 86 (1988). See generally Transnational Law Database, http://www.tldb.net (last visited Apr. $27,2008)$ (collecting references on transnational commercial law).

46. Mustill, supra note 45 , at 114 . 
created law because "[p]olitically dictated rules are not designed to support the market process; in fact government made law is likely to do precisely the opposite." ${ }^{47}$ Others are more critical. They assert that the new Law Merchant permits private parties to "usurp[] the governing law and the controls that a particular national community deems necessary for commercial transactions occurring within its space." Professor Carbonneau and François Janson:

At the end of the day, transborder adjudication will be guided by the dictates of the marketplace and the international commercial community and completely exempt from the reach of sovereign national authority. Law will be generated within the confines of a fully privatized system that is unaccountable to any public organization or process. Arbitrators, lawyers, arbitral institutions, and law firms will become the de facto government and the courts of international trade and commerce.

But whether this is likely to happen depends on the extent to which parties in fact seek to have the new Law Merchant apply to their contracts.

Again, there are conflicting views. Some argue that the new Law Merchant is too general and vague to provide meaningful guidance to parties. This uncertainty, the argument goes, would make it unattractive to parties, and thus we would not expect them to rely in any significant way on the new Law Merchant in their contracts. ${ }^{50}$ Others have asserted the opposite. For example, in a recent Green Paper, the European Commission stated:

It is common practice in international trade for the parties to refer not to the law of one or other state but direct to the rules of an international convention such as the Vienna Convention of 11 April 1980 on contracts for the international sale of goods, to the customs of international trade, to the general principles of law, to the lex mercatoria or to recent private codifications such as the UNIDROIT Principles of International Commercial Contracts. ${ }^{51}$

47. Bruce L. Benson, The Spontaneous Evolution of Commercial Law, 55 S. ECON. J. 644, 661 (1989).

48. W. Michael Reisman, Systems of Control in International Adjudication and ARBITRATION 138 (1992).

49. Thomas E. Carbonneau \& François Janson, Cartesian Logic and Frontier Politics: French and American Concepts of Arbitrability, 2 TUL. J. INT'L \& COMP. L. 193, 221-22 (1994).

50. See Drahozal, supra note 44, at 534-35.

51. Green Paper on the Conversion of the Rome Convention of 1980 on the Law Applicable to Contractual Obligations into a Community Instrument and Its Modernisation, at 22, COM (2002) 
Although the Commission's assertion is an empirical one, it provides no evidence in support. Time for MythBusters again. ${ }^{52}$

Data from the ICC are helpful in testing this myth as well. ${ }^{53}$ Each year, the ICC reports summary data on the applicable law specified in arbitration clauses that give rise to disputes arbitrated before it. ${ }^{54}$ Table 1 summarizes those data for the years 2003-2006 (the results from prior years are comparable). Each year, only $1 \%$ to $2 \%$ of the clauses specify some a-national rules of decision to govern any dispute that may arise. For example, out of 644 contracts giving rise to ICC arbitrations in 2003 the ICC identified the "[o]ther rules or principles occasionally chosen" as "EC law (one contract), general principles of equity (two contracts), international law (one contract), international commercial law (one contract) and the United Nations Convention on Contracts for the International Sale of Goods (three contracts). ${ }^{, 55}$ By comparison, almost $80 \%$ of the arbitration clauses that give rise to ICC arbitrations specify a particular national law to govern. In short, at least as to ICC arbitrations, the myth that parties contract for application of the new Law Merchant in any significant way appears to be busted.

\begin{tabular}{|l|r|r|r|r|}
\hline \multicolumn{5}{|c|}{ Table 1. Applicable Law in ICC Arbitration Clauses } \\
\hline & 2003 & 2004 & 2005 & 2006 \\
\hline National Law & $80.4 \%$ & $79.1 \%$ & $79.3 \%$ & $82.7 \%$ \\
\hline Other Rules & $1.2 \%$ & $1.3 \%$ & $1.7 \%$ & $2.0 \%$ \\
\hline $\begin{array}{l}\text { Applicable Law Not } \\
\text { Specified }\end{array}$ & $18.3 \%$ & $19.6 \%$ & $19.0 \%$ & $15.3 \%$ \\
\hline
\end{tabular}

Source: Annual Statistical Reports, ICC INT’L Ct. ARB. BuLl. (2004-2007).

654 final (Jan. 14, 2003) (emphasis added).

52. Interestingly, historians have begun questioning whether the medieval law merchant in fact was a complete and autonomous body of law as well. E.g., Charles Donahue, Jr., Medieval and Early Modern Lex mercatoria: An Attempt at the probatio diabolica, 5 CHI. J. INT’L L. 21, 36 (2004); Emily Kadens, Order Within Law, Variety Within Custom: The Character of the Medieval Merchant Law, 5 CHI. J. INT'L L. 39, 40 (2004); Oliver Volckart \& Antje Mangels, Are the Roots of the Modern Lex Mercatoria Really Medieval?, 65 S. ECON. J. 427, 437 (1999).

53. For more detailed discussion, see Drahozal, supra note 44, at 537-40.

54. 2003 Statistical Report, ICC InT'L Ct. ARB. BUll., Spring 2004, at 7, 13; 2004 Statistical Report, ICC INT'L Ct. ARB. Bull., Spring 2005, at 5, 11; 2005 Statistical Report, ICC INT'L CT. ARB. Bull., Spring 2006, at 5, 11; 2006 Statistical Report, ICC INT’L CT. ARB. Bull., Spring 2007, at 5,11 .

55. 2003 Statistical Report, ICC InT’L Ct. ARB. BULL., Spring 2004, at 7, 13. 
Another source of data is the provisions of publicly available international arbitration clauses. Several researchers have examined the dispute resolution clauses in contracts attached to corporate disclosure filings made with the Securities and Exchange Commission. ${ }^{56}$ In a sample of international joint venture agreements available in SEC filings (from 1993 to 1996), 26.7\% (four of fifteen) referred to "general international commercial practices" as the rules of decision. ${ }^{57}$ All of these clauses were in contracts between U.S. and Chinese parties, however, and typically by their terms specified that arbitrators were to apply such general practices only "if there is no published and publicly available law in China pertaining to any particular matters relating to this Contract." 58 In other words, parties were contracting to apply the new Law Merchant not to supplant national law, but only to supplement national law that was incomplete or unavailable. Although parties may refer to the new Law Merchant (at least in some settings) more frequently than the ICC data indicate, the available evidence suggests that the reason in those cases may be the opposite of what usually has been asserted. The myth is still busted.

\section{MYTH 3: Do ARBITRATORS “SPLIT THE BABY”-I.E., MAKE COMPROMISE AWARDS?}

A commonly stated view about how arbitrators decide cases is that they "split the baby" - that is, they make awards that compromise between the parties' positions. The phrase "split the baby" obviously has a long history: in the Old Testament, by threatening to "split the baby," King Solomon was able to identify the true mother of the child. ${ }^{59}$ This biblical story has been analyzed from various perspectives, from game theory ("as a game Solomon devised to test the veracity of the women's claims" ${ }^{\circ 0}$ ) to feminist legal theory ("the judge outsmarts the women, uses their bodies and instincts against them, and treats them as objects" ${ }^{\prime 61}$ ).

56. E.g., Eisenberg \& Miller, supra note 14

57. Drahozal, supra note 44 , at 540-41.

58. Id. at 541 (quoting Contract Between Tianjin Economic-Technological Development Area Business Development Co. and AST Research (Far East) Ltd. art. 26.1).

59. 1 Kings 3:16-28.

60. Steven J. Brams, Negotiation Games: Applying Game Theory to Bargaining and Arbitration 18 (rev. ed. 2003); see also Steven J. Brams, Biblical Games: A STrategiC ANALYSIS OF STORIES IN THE OLD TESTAMENT 118-23 (1980).

61. Orit Kamir, Feminist Law and Film: Imagining Judges and Justice, 75 CHI.-KENT L. REv. 899, 905 (2000); see also Ann Althouse, Beyond King Solomon's Harlots: Women in Evidence, 65 S. CAL. L. REV. 1265 (1992); Marie Ashe, Abortion of Narrative: A Reading of the Judgment of Solomon, 4 YALE J.L. \& FEMINISM 81 (1991). 
Interestingly, a very similar story appears in Buddhist and Chinese texts (and in folktales from a number of other countries). ${ }^{62}$ Indeed, the Chinese play Huilan ji (The Chalk Circle) was the inspiration for Bertolt Brecht's The Caucasian Chalk Circle ${ }^{63}$ which similarly involves a woman who refuses to "split the baby" and thus identifies herself as the "true mother" (even though she was not the child's biological mother). ${ }^{64}$ Presumably, though, it was the King Solomon version that inspired a more recent dramatization of the story in the TV sitcom Seinfeld. An episode entitled "The Seven" illustrates both the myth and, more basically, an example of the arbitration process. ${ }^{65}$

In the episode, Elaine, played by Julia Louis-Dreyfus, is shopping with Jerry (Jerry Seinfeld) at a used goods store. Elaine decides that she wants to buy a used girl's Schwinn Stingray bike. As she tries to take the bike down off the wall, it falls on her and hurts her neck. When they get back to Jerry's apartment, she feels miserable and says, "You know, right now I would give that bike to the first person who could make my neck feel better." Kramer, played by Michael Richards, walks up to her, mumbles some words, and twists her neck. Elaine says, "Wow, my neck feels great. You did it, Kramer." Kramer responds: "Send the bike over anytime."

Elaine refuses, asserting that her offer was not serious. Kramer insists that she should be held to her promise because "we need to be able to take people at their word." Jerry steps in, suggesting that they get an "impartial mediator" to resolve their dispute: "someone with no emotional attachment, a heart so dark it cannot be swayed by pity, emotion, or human compassion of any kind"-Newman, their next door neighbor.

The first thing Newman does is make Elaine and Kramer promise to abide by whatever decision he makes. The binding nature of the third party's decision is a hallmark of arbitration. Jerry thus is wrong when he describes Newman as an "impartial mediator"-Newman is an arbitrator.

62. Simon J. DeVries, 12 Word Biblical Commentary 58 (Bruce M. Metzger et al. eds., 2003); Paul G. Brewster, Solomon's Judgment, Mahosadha, and the Hoei-kan-li, 21 FolKLORE STUD. 236, 236-38 (1962).

63. Wenwei Du, The Chalk Circle Comes Full Circle: From Yuan Drama Through the Western Stage to Peking Opera, 12 Asian TheATRE J. 307, 314 (1995).

64. Bertolt Brecht, The Caucasian Chalk Circle 12 (Eric Bentley trans., Univ. of Minn. Press 1999) (1947) ("It's called The Chalk Circle and comes from the Chinese. But we'll do it, of course, in a changed version."); see Michael Freeman, Truth and Justice in Bertolt Brecht, 11 CARDOZO STUD. L. \& LiT. 197, 203-04 (1999).

65. Seinfeld: The Seven (NBC television broadcast Feb. 1, 1996). For a description of the episode, see Christopher R. Drahozal, Privatizing Civil Justice: Commercial Arbitration and the Civil Justice System, 9 KAN. J.L. \& PUB. POL’Y 578, 578-79 (2000). 
Eventually, Newman makes his award and orders that the bicycle be cut in half, with Elaine and Kramer each to get half. Elaine is disgusted with the whole process and says, "Sure, go ahead and cut the bike in half." Kramer, however, insists that the bike be kept whole, and is willing to give it to Elaine rather than have it cut in half. Then, like Solomon, Newman finds Kramer to be the "true" owner of the bicycle and awards it to him.

Of course, neither Newman nor King Solomon actually "split the baby" (or the bicycle, as the case may be); they only threatened to do so. But the arbitration myth goes beyond threats: according to the myth, arbitrators actually make compromise awards. The theory is that in making decisions, arbitrators want to keep both parties happy. Otherwise, the arbitrator might not get selected for a future case. As a result, one might expect, as Judge Richard Posner has stated, "a tendency for arbitrators to 'split the difference' in their awards, that is, to try to give each side a partial victory (and therefore partial defeat)."

A study by Stephanie Keer and Richard Naimark tests this myth. ${ }^{67}$ They examined a sample of AAA international arbitration awards and found that the mean arbitration award was $50.53 \%$ of the amount demanded (and the median award was $46.66 \%$ of the amount demanded). ${ }^{68}$ On their face, these results would seem to support the myth - parties on average recovered half of what they sought. But when the awards are plotted on a graph, a very different picture appears. As Figure 1 illustrates, the distribution is bimodal - in the substantial majority of awards, the claimant recovers either all or none of what it demanded, which would result in a mean award of $50 \%$, but which is inconsistent with the myth. ${ }^{69}$ The results of a follow-up study by the AAA, shown in Figure 2, are similar (albeit not quite as stark). ${ }^{70}$

66. Richard A. Posner, Judicial Behavior and Performance: An Economic Approach, 32 FLA. St. U. L. REV. 1259, 1260-61 (2005). Alan Scott Rau has stated:

The dynamic of arbitrator self-interest has long been familiar in collective bargaining cases and is thought, for example, to provide one explanation for the apparently common practice of compromise awards. Repeat business for the arbitrator is likely only if he is able to retain the future goodwill of both union and management; the desire to do so may give him an incentive (in the hallowed phrase) to "split the baby" in a single arbitration, or it may be "reflected in a course of decisions by the same arbitrator which over time, taken together, appears to show a rough balance between awards favorable to labor and those favorable to management."

Alan Scott Rau, Integrity in Private Judging, 38 S. TEX. L. REV. 485, 523 (1997) (citations omitted). 67. Stephanie E. Keer \& Richard W. Naimark, Arbitrators Do Not "Split the Baby": Empirical Evidence from International Business Arbitrations, 18 J. INT'L ARB. 573 (2001).

68. Id. at 574 .

69. Id. at 575 .

70. Splitting the Baby: A New AAA Study (Mar. 9, 2007), http://www.adr.org/sp.asp?id=32004. 
FIGURE 1. KEER \& NAIMARK RESULTS (2001)

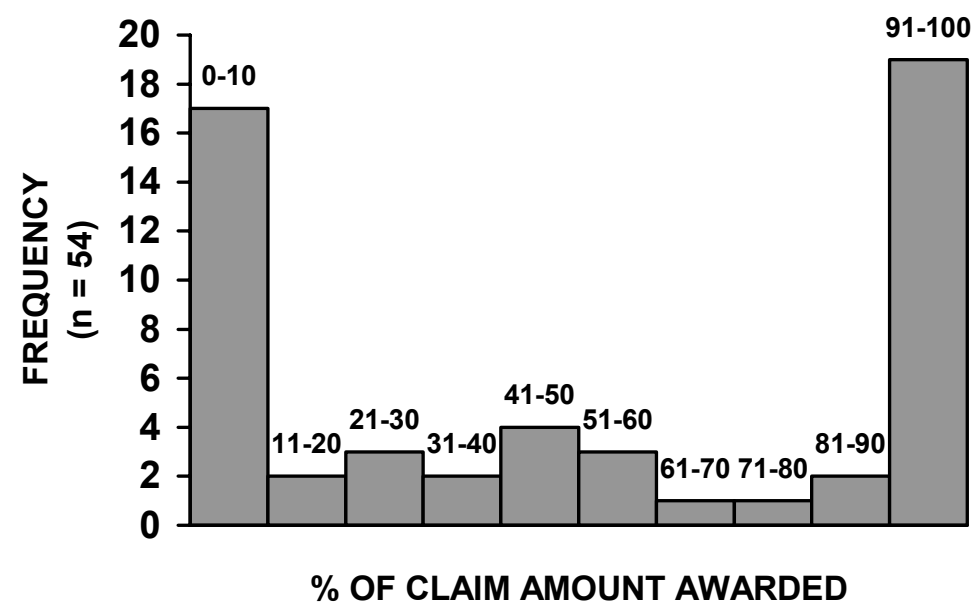

FigURE 2. AAA FOLLOW-UP STUDY (2007)

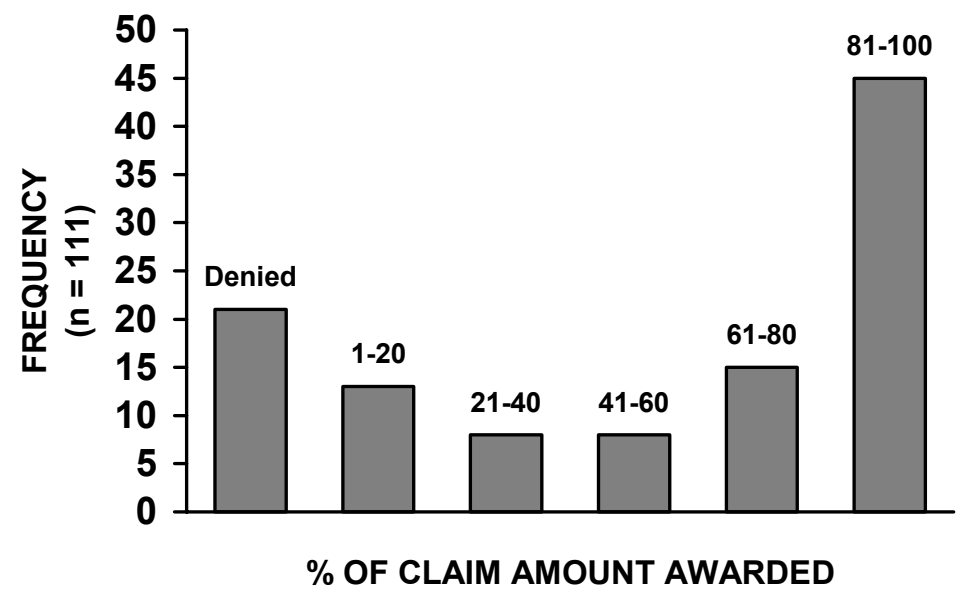


Of course, these results are not conclusive. It may be that arbitrators do make compromise awards in a small handful of cases, giving rise to the myth. Or arbitrators may split the difference across several cases involving the same parties (ruling in favor of one party in one case and the other in the next), rather than compromising in every individual case. Or the AAA arbitrations may be anomalous. Nonetheless, based on the evidence to date, this myth is busted.

\section{CONCLUSION}

To recap the arbitration myths examined here: (1) the myth that the number of arbitration proceedings held in a country increases after it enacts a new arbitration statute is confirmed, although to nowhere near the extent predicted by some supporters of new arbitration laws; (2) the myth that parties commonly agree to have their disputes resolved under the new Law Merchant in lieu of national law is busted; and (3) the myth that arbitrators "split the baby" (or bicycle)—i.e., make compromise awards - is busted as well. More generally, I hope to have provided at least some indication that a MythBusters-type approach-subjecting commonly held views to empirical testing - is useful not only for urban legends, but also in understanding the legal system, including international arbitration. 